\title{
OSMANLI ERKEN MODERN DÖNEMİNDE EGEMENLİĞİN SÜREKLİLİĞİ SORUNU VE DEVLET TÜZEL KIŞİLIĞİNIN GELİŞIMİ (1453-1617)
}

\begin{abstract}
Ensar KIVRAK*
Makale Geliş Tarihi-Received: 15.02.2021

Makale Kabul Tarihi-Accepted: 20.10.2021

DOI: $10.37093 /$ ijsi.880809

ÖZ

Bu çalışmanın konusu, Osmanl Erken Modern Çağında egemenliğin sürekliliği sorunu ve bununla bağlantıl olarak devlet tüzel kişiliğinin gelişimidir. Çalışma, egemenlikte sürekliliğ̈inin sağlanması ile devlet tüzel kişiliğinin gelişimi arasında bir iliş̧i olduğu ve bu sürekliliğin, devlet tüzel kişiliğinin gelişimine zemin hazırladığı hipotezine dayanmaktadır. Çalışmada öncelikle Osmanlı'da egemenliğin kimde olduğu tartışılmıştır. Buna göre önceleri hanedanda tecessüm eden egemenliğin Erken Modern Çağda padişahın şahsında toplandı̆̆ ortaya konmuştur. Ardindan, devlet tüzel kişiliğinin gelişim seyrini gösterebilmek için Osmanlıların kendine verdikleri isimler tahlil edilmiştir. Böylece devlet tüzel kişiliğinin ortaya çıkışına dair ipuçlarn gösterilmiştir. Bu süreçte yaşanan tarihsel gelişmelere değinilerek devlet tüzel kişiliğinin ortaya çıkışında ve gelişiminde etkili olan temel faktörler ele alınmıştır. Son olarak egemenliğin sürekliliği sorunu bir padişah öldüğ̈̈nde yerine geçecek olanın kim olacağ ve nerede tahta cülus edeceği örneği etrafinda tartışılmıştır. Çalışmanın sonunda, Osmanlı Erken Modern Çağında önce hanedandan bağımsız ve mutlak saltanat anlayışının ve daha sonra sultandan bağımsız ve müstakil bir devlet anlayışının geliştiği ve
\end{abstract}

* Araştırma Görevlisi, Sakarya Üniversitesi, Siyaset Bilimi ve Kamu Yönetimi Bölümü, Sakarya/Türkiye. ensarkivrak@sakarya.edu.tr, ORCID: https://orcid.org/0000-0002-2248-0127. 


\section{Ensar KIVRAK}

dolayısıyla süreklilik sorununu belli ölçüde aşıldığı, kıymeti kendinden menkul bir devlet tüzel kişiliğinin oluşmaya başladı̆̆ı sonucuna ulaşılmıştır.

Anahtar Kelimeler: Egemenlik, Devlet Tüzel Kişiliği, Osmanlı Hanedanlığı, Osmanlı Devleti. 


\title{
THE PROBLEM OF CONTINUITY OF SOVEREIGNTY AND THE DEVELOPMENT OF STATE LEGAL ENTITY IN THE OTTOMAN EARLY MODERN PERIOD (1453-1617)
}

\begin{abstract}
The subject of this study is the problem of the continuity of sovereignty and the development of the state legal entity in connection with this in the Ottoman Early Modern Age. The study is based on the hypothesis that there is a relationship between ensuring the continuity of sovereignty and the development of the state legal entity, and this continuity lays the groundwork for the development of the state legal entity. In the study, first of all, who was the sovereign in the Ottoman Empire was discussed. Accordingly, it has been revealed that the sovereignty, which was once embodied in the dynasty, was gathered in the person of the sultan in the Early Modern Period. Then, the names given by the Ottomans to themselves were analyzed in order to show the development course of the state legal entity. Thus, clues about the emergence of the state legal entity are shown. By referring to the historical developments experienced in this process, the main factors influencing the emergence and development of the state legal entity are discussed. Finally, the question of the continuity of sovereignty is discussed around the example of who will replace a sultan when he dies and where he will conquer the throne. At the end of the study, it was concluded that in the Ottoman Early Modern Period, firstly, the understanding of absolute sultanate and independent from the dynasty and then an independent and separate state understanding from the sultan developed and therefore, it was concluded that the problem of continuity has been overcome to a certain extent and that a state legal entity has started to form.
\end{abstract}

Keywords: Sovereignty, State Legal Entity, Ottoman Dynasty, Ottoman Empire. 


\section{Gíriş}

Günümüzde adına devlet dediğimiz siyasal yapının temel özelliklerinden birisi, egemenlik alanı içinde yaşayan insanlardan farklı, soyut ve kurumsal kimliğe yani bir tüzel kişiliğe sahip olması ve devlet adına hareket eden memurlardan ve yöneticilerden ${ }^{1}$ farklılaşmış olmasıdır (Uslu, 2017: 18, Wood, 2002: 19'dan). Bu çalışmada, bu farklılaşma sürecinden önce hanedan ile devletin bir ve aynı şey olarak anlaşıldığı ve dolayısıyla egemenliğin hanedanda tecessüm ettiği ön kabulünden hareket ederek öncelikle hanedan ile padişahın şahsının; ardından da padişahın şahsı ile devletin (devlet tüzel kişiliğinin) birbirinden ayrılması/ayrı düşünülmesi süreci tartışılmaktadır. Dolayısıyla çalışmanın temel savı, egemenliğin bir bütün olarak hanedan yerine padişahın şahsında tecessüm etmesiyle padişahın mutlak egemen haline geldiği; padişaha bağlı olarak gelişen pre-modern askeri ve bürokratik yapılanmaların devlet tüzel kişiliğinin ortaya çıkışına zemin hazırladığı ve bu tüzel kişi düşüncesi bir kez ortaya çıtıktan sonra onu mümkün ve sürdürülebilir kılan şeyin ise egemenliğin süreklilik unsuru olduğu şeklinde özetlenebilir. $\mathrm{Bu}$ noktada egemenliğin bir unsuru olarak süreklilik, egemenliğin sürekli var olmasını; kesintiye uğramamasını ifade etmektedir. Örneğin egemenliği elinde bulunduran bir kralın/hükümdarın ölümü, tebaada egemenin ortadan kalktığı ve dolayısıyla kendisine tabi olunan bir otoritenin kalmadığı intibaını uyandırmamalı ve halef selef ilişkisi içerisinde egemenliğin kendisinde tecessüm ettiği krallar/hükümdarlar değişebilirken bu egemenliğin esas sahibi olarak görülen devlet veya hanedan gibi temel siyasi birimler sabit kalmalıdır.

Joseph R. Strayer, Modern Devletin Kökenleri [1970] (2020) adlı eserinde, Orta Çă ve Erken Modern Çağ boyunca Avrupa devletlerinin kurumsallaşması bağlamında yaşanan gelişmeleri ele alarak feodal siyasi yapının bozulmasıyla birlikte mutlak monarşilerin oluşumuna giden süreci betimlemektedir. Bu süreçte özellikle hukuk ve maliyenin gelişmesini ve kurumsallaşmasını önemli adımlar olarak

1 Bu çalışmanın konusu açısından memurlardan kasıt İlmiye, Kalemiye ve Seyfiye sinıfları; yöneticiden kasıt ise padişahtır. 


\section{Osmanlı Erken Modern Döneminde Egemenliğin Sürekliliği Sorunu ve Devlet Tüzel Kişiliğinin Gelişimi (1453-1617)}

görmektedir. 1450-1600 yılları arasında ${ }^{2}$ egemenlik düşüncesinde yaşanan değişim ve buna toplumsal desteğin artması gibi faktörlerle yeni monarşiler olarak adlandırılan erken-modern devletlerin ortaya çıkışını açıklamakta ve bu süreçte yeni karar alma mekanizmalarının oluşumu ile profesyonel bürokrasinin ortaya çıkışını, modern devlete giden dönüşümde en önemli adımlar olarak değerlendirmektedir (Strayer, 2020: Üçüncü Bölüm). Strayer, devletin tüzel kişilik kazanması meselesine doğrudan değinmemiş olsa da onun bahsettiği bu gelişmeler, esasında devlet tüzel kişiliğinin şekillenmesinde etkili olmuştur.

Ernst H. Kantorowicz ise Kralın İki Bedeni [1957] (2018) adlı eserinde aynı dönemde İngitere'de hanedanın ve devletin bazı unsurlarının sürekliliği sorununu ve tüzel kişiliğin ortaya çıkışını tasvir etmektedir. Örneğin bir kral öldüğünde yerine yeni kral geçene kadar ortaya çıkan fetret döneminde, ortada bir egemenin kalmadığı ve dolayısıyla kendilerini bağlayıcı bir yasa olmadığı gerekçesiyle halkın kendisini yağma yapma hakkına sahip görmesi düşüncesinin zamanla geliştirilen hukukî savlarla nasıl bertaraf edildiğini (Kantorowicz, 2018: 417-442) ya da kraln iki bedeni kurgusundaki siyasi bedenin zamanla nasıl tek başına kralı temsil etmekten çıkarak kral, lordlar ve parlamento ile birlikte birleşik bir beden anlayışına dönüştüğünü ve böylece devlet merkezli krallı düşüncesinin oluşarak devlet tüzel kişiliğinin gelişim sürecinde bir aşama oluşturduğunu (Kantorowicz, 2018: 277-302) göstermektedir. Dolayısıyla İngiltere örneği tıpkı Osmanlı' da olduğu gibi monarkın/padişahın şahsında tecessüm eden egemenliğin devlet tüzel kişiliğinin gelişimiyle birlikte zamanla monarktan/padişahtan devletin soyut/manevi şahsına doğru geçişini de göstermektedir.

Ancak muhtemelen Osmanlı Hanedanlığı ya da Osmanlı Devleti için kralın iki bedeni ya da devletin farklı unsurlarını birleşik bir bedende bir araya getiren siyasi beden gibi belirgin kurgular yoktu. Fakat Osmanlı Devleti de süreklilik -daha doğru bir ifadeyle egemenin

2 Bu çalışmanın kapsamı da Strayer'in 1450-1600 şeklindeki dönemlendirmesine paralel olarak Fatih Kanunnamesi'nin devlet teşkilatlanmasını yeni baştan kurmasından itibaren I. Ahmet'in saltanat döneminin sonuna kadar olan dönemi temsilen 1453-1617 tarih aralığ olarak belirlenmiştir. 
sürekli var olması- ile ilgili bir dizi sorunu kendi içerisinde barındırıyordu $\mathrm{ki}$ bu çalışma egemenin sürekliliği sorununun aşılmasının devlet tüzel kişiliğinin gelişiminde nasıl önemli bir rol oynadığını göstermeyi de hedeflemektedir.

Bu çalışmada öncelikle Eski Türklerden Osmanlı' ya değin egemenlik anlayışından kısaca bahsedilecektir. Nitekim bir devlet tüzel kişiliğinin gelişiminden ve devletin sürekliliğinden bahsedilecekse, öncelikle bu süreçte egemenin kim olduğuna karar vermek gerekmektedir. Bu süreçte önceleri bir bütün olarak hanedanın egemen unsur olarak kabul edildiği; fakat ardından hanedanın egemenlikteki bu konumunu yitirerek egemenliğin saltanatta yani bizatihi padişahın kendisinde tecessüm etmeye başladığ1 gösterilecektir. Egemenlik konusuna böylece açıklık getirildikten sonra hanedandan ve sultandan bağımsız bir devlet telakkisinin yani aslında bir devlet tüzel kişiliğinin tarihsel bir süreç içerisinde geliştiğini gösterebilmek amacıyla Osmanlıların kendisini nasıl isimlendirdiği sorusuna cevap verilecektir. Böylece hanedandan ve sultandan bağımsız bir devlet telakkisinin varlığı ortaya konduktan sonra bu telakkinin gelişim süreci, bugün ismine devlet dediğimiz siyasal organizasyon içerisindeki merkezi güç odaklarının değişimi/dönüşümü üzerinden izlenecektir. Son olarak, Osmanlı sultanlarının tahta cülusu örneğinden hareketle Osmanlı' da egemenin sürekliliği sorunu tartışılacaktır. Nitekim sürekli var olan bir devlet telakkisinin oluşması yani aslında devletin bir tüzel kişilik olarak görülmesi, devletin temel özelliklerinden olan egemenliğin ve dolayısıyla egemenliğin temel özelliklerinden olan (egemenlikte) sürekliliğin sağlanmasıyla yakından ilgilidir.

\section{ESKİ TÜRKLER'DEN OSMANLI'YA EGEMEN: HANEDAN}

Egemenlik kavramı, Avrupa'da modern devletlerin gelişimine bağlı olarak on altıncı yüzyılda Jean Bodin (1530-1596) tarafından geliştirilmiş bir kavramdır. Egemenlik; sınırsız, mutlak, tek, bölünemez ve devredilemez bir iktidarı ifade etmektedir (Bodin, 2003:1). Fakat Bodin, egemenin gücünü sınırlandıracak şekilde Tanrı'nın iradesi ve doğal hukuk gibi egemenden üstün olan bir hukukun varlığını da kabul eder (Heywood, 2014: 110-111). 


\section{Osmanlı Erken Modern Döneminde Egemenliğin Sürekliliği Sorunu ve Devlet Tüzel Kişiliğinin Gelişimi (1453-1617)}

Bu tanımın ifade ettiği tarihsel bağlama benzer şekilde Türklerde de töre olarak ifade edilen kurallar kümesi, egemenliğin belirlenmesinde ve egemenin sınırlandırılmasında belirleyici konumdadır. Dolayısıyla egemen konumda olan hükümdar, ancak töreye uyduğu sürece meşru görülmüştür (İnalcık, 1959: 75). Bu sebeple Türklerde sınır tanımaz egemenliğe sahip olan bir hükümdardan bahsetmek mümkün değildir (Kafesoğlu, 1997: 246).

Orhun Kitabelerinden, Eski Türklerde egemenliğin kut kelimesi ile ifade edildiği ve kutun Gök Tanrı' dan geldiği inancının hâkim olduğu anlaşılmaktadır. Ancak bu noktada kutun hükümdarın şahsına değil hanedana ait olduğu (İnalcık, 1959: 82; Kafesoğlu, 1980: 33); hükümdarın töreye uymaması halinde ise Tanrı tarafından kutun hükümdardan alınabileceği ve böylece hükümdarın tahttan indirilebileceği kabul edilmektedir. Fakat bu noktada itaatsizliğin hanedana değil; töreye uymayan ve kutunu kaybeden hükümdara karşı olduğunu özellikle vurgulamak gerekmektedir. Buradan da anlaşılacağı üzere kutun/egemenliğin asıl sahibi hanedandır ve hükümdarlar, hiçbir zaman keyfi ve sınırsız iktidar sahibi olamamaktadır (Taşağıl, 1992: 104-5).

Öte yandan kutun temelde hanedana ait olması anlayışının, iki sorun alanını da beraberinde getirdiği söylenebilir. Birincisi, bu anlayışın hanedan içerisinde meydana gelebilecek taht kavgalarının meşruiyetine de zemin hazırlamasıdır (Kösoğlu, 1997: 46). İkincisi ise ülüş sisteminin bir sonucu olarak hanedan üyelerinin egemenlikten pay almasıdır. Hanedan üyelerinden birisi hükümdar olsa dahi aslında hanedanın tüm erkek üyelerinin potansiyel olarak ülke yönetimine katılma hakları vardı ve fiilen hükümdarın kendilerine bıraktıkları bölgeleri -tabiri caizse özerk bir yönetim anlayışı çerçevesinde- yönetmekteydiler (Özdemir, 2009: 4, 6).

Türklerin İslamiyet'e geçişiyle birlikte ise İslamî geleneklerle İslam öncesine ait egemenlik anlayışının bağdaştırıldığı; örneğin İslam'ın aslî kaynaklarında rastlanmamasına rağmen kutsal hanedan anlayışının devam ettirildiği görülmektedir (Güngör, 1996: 159). Padişahların resmî unvan olarak İslamî kökenden gelen sultan ve Türk kökenden gelen han unvanlarını birlikte kullanması -örneğin Fatih Sultan Mehmed Han-, bu duruma örnek olarak gösterilebilir (Peirce, 1996: 22). Dolayısıyla İslam öncesi var olan egemenlik anlayışının İslamiyet'le birlikte sürdürüldüğü de söylenebilir. Açıkçası bu durum, 
Türklerde Müslüman olmanın getirdiği biçimsel bir değişim dışında özü itibariyle aynı egemenlik anlayışının sürdürüldüğünü göstermektedir (Özdemir, 2009: 8-9). Son tahlilde "her hal ü kârda Osmanlı hanedanında hakimiyetin menşei telakkisinde Orta-Asya Türk geleneği devam etmiştir" (İnalcık, 1959: 81).

Bilindiği üzere, kuruluşundan itibaren Osmanlı, dönemin -belki de bütün- diğer devletlerinde olduğu gibi bir hanedanlık idi. Dolayısıyla yönetme yetkisi hanedan ailesine aitti ve hanedan içerisinden yönetme yetkisi kendisine nasip olan kişi, sultan oluyordu. Şu hâlde devlet ve hanedan, bir ve bütün şeylerdi.

Fakat on beşinci yüzyıldan itibaren devletin artık hanedanın ortak bir mirası gibi düşünülmediği; padişahın, egemenliğin tek sahibi olduğu görülmektedir (İnalcık, 1959: 94; Akyılmaz, 1999: 137). Erken Modern Çağ boyunca egemenlik düşüncesinde yaşanan bu dönüşümler, devlet tüzel kişiliğinin teşekkülü bağlamında incelenebilir. Bu bağlamda öncelikle devlet tüzel kişiliğinin ortaya çıkışı Osmanlıların kendini nasıl isimlendirdiği sorusu etrafında ortaya konmuş; ardından devlet tüzel kişiliğinin gelişim süreci, siyasal organizasyon içerisindeki merkezî güç odaklarının değişimi ve dönüşümü üzerinden izlenmiştir.

\section{DEVLETIN İSİMLENDİRILMESİ SORUNU}

Bir beylik olarak ortaya çıan Osmanlıların kendilerini nasıl isimlendirdikleri sorunu, hanedanlıktan bir devlet telakkisine doğru yaşanan dönüşümün seyrini ortaya koymaya yardımcı olabilir. Bu konuda Christoph K. Neumann'ın Devletin Adı Yok - Bir Amblemin Okunması (1999) adlı makalesi, önemli ipuçları sunmaktadır. Neumann'a göre (1999: 280) farklı dönemler için farklı farklı isimler koymak gerekmektedir. Farklılaşan bu isimlerin zaman içindeki değişim seyri de Osmanlı'da devlet tüzel kişiliğinin teşekkülü bağlamında değerlendirilebilir.

Bu bağlamda ilk olarak on beşinci yüzyılın hemen başlarında ilk Osmanlı tarihçisi olarak kabul edilen Ahmedî’nin (1334-1413) 


\section{Osmanlı Erken Modern Döneminde Egemenliğin Sürekliliği Sorunu ve Devlet Tüzel Kişiliğinin Gelişimi (1453-1617)}

Osmanîler ${ }^{3}$ tabirini kullandığı bilinmektedir (Emecen, 2012: 43). Yine on beşinci yüzyıl Osmanlı tarihi yazarları, eserlerine Tevarih- $i$ Al-i Osman yani Osmanl Hanedanının Tarihleri ismini vermektedirler. Kanuni Sultan Süleyman döneminde şeyhülislamlık yapan İbn Kemal (Kemalpaşazade)'in (1468?-1536) aynı isimli eserinde de -herhangi bir devlet tüzel kişiliğini vurgular nitelikte- Devlet-i Aliyye tabiri hiç geçmemektedir. Benzer şekilde Gelibolulu Mustafa Ali (1541-1600), 1581'de kaleme aldığı ve günümüz Türkçesine Siyaset Sanatı olarak aktarılan Nushatü's-Selatin adlı eserinde devlet kelimesini hiç kullanmamaktadır. Buradan çıkarılacak sonuç, on altıncı yüzyıl sonuna değin isimlendirmede kurumsal bir yapı olarak devlet tabirine yer verilmediği; isimlendirmede hanedanın esas alındığı yönünde olmalıdır. Fakat bu geleneğin Fatih Sultan Mehmet döneminde kardeş katlinin kurumsallaşması ile bozulduğu söylenebilir. Bu tarih itibarıyla, -padişah devletin ta kendisi demek değildir belki amahanedan önemini kaybetmeye başlamış; devlet bizatihi sultanın kendi şahsında somutlaşır olmuştur (Neumann, 1999: 277). Örneğin Kanuni Sultan Süleyman, kendi ülkesi için "Memalik-i Mahsusem" yani "korunmuş memleketlerim" demektedir (İnalcık, 1965: 104)

Diğer taraftan Ayn Ali Efendi (?-?), Kavânîn-i Âl-i Osmân der Hulâsa-i Mezâmîn-i Defter-i Dîvân (1607) adlı kanun derlemeleri olan eserinde devlet kelimesine yer vermekle beraber bunu tüzel kişiliği haiz kurumsal bir siyasi yapıyı nitelemek için değil hükümdarın iktidarını nitelemek için kullanır. Yaklaşık 1620'ye tarihlenen ve yazarı belli olmayan Kitab-ı Müstetab ise sistematik bir şekilde Devlet-i Aliyye tabirini kullanmaktadır. Fakat bu kullanım, artık hanedan isminin işlevsizleştiği anlamina da gelmemektedir. Örneğin yazar, özellikle kanunlardan bahsederken daima hanedan ismini vurgulayarak kanunı Al-i Osman tabirini kullanmaktadır. Neticede denilebilir ki on beşinci yüzyıl boyunca genelde hanedan ve özelde padişah, kilit konumlarını koruyor; kurumlar ve kanunlar ondan neşet ediyordu. Fakat bununla beraber artık daha soyut ve yüceltilmiş bir devlet kavraminın varlığından da söz etmek mümkündü (Neumann, 1999: 278-279).

3 Osmanlılık kimliğinin ilk ortaya çıkışı, bu çalışmanın kapsamı dışında kaldığı için burada ele alınmamıştır. Ancak bu konuda ayrıntılı bilgi için şu kaynağa bakılabilir: Emecen, Feridun. (2012). İlk Osmanlılar ve Batı Anadolu Beylikler Dünyası. İstanbul: Tİmaş Yayınları, "“Tavâif-i Mülûk'dan" Osmanlılaşmaya" başlığı. 
Mustafa Efendi Naima'nın (1655?-1716) orijinal ismi Ravzatü'l-Hüseyn fî hulâsati ahbâri'l-hâfikayn (1702) olan fakat kısaca Tarih-i Naima ismiyle bilinen eserinde ise devlet kavramı açı bir şekilde tanımlanır ve daha sonra bu tanım, Osmanlılar tarafından yaygın olarak kullanılır. Bu tarihten sonra, Osmanlı aydın ve bürokrat kesimi için Osmanlı saltanatını bir devlet olarak ele alma eğilimi oluşmuş görünmektedir (Neumann, 1999: 279). Naima'nın eserinin henüz başında yer alan devlet tanımı ise tam olarak şöyledir: "Ma'lum ola ki mülk ve saltanat ma'nâsına olan devlet bir nev' âyin üzre ictima'-i beşeriyyeden ibarettir" (İpşirli, 2007: 21). Fakat yine de bu dönemde bile Devlet-i Aliyye'yi padişahla özdeşleştirme eğiliminin devam ettiği de (Neumann, 1999: 279) belirtilmelidir. Nitekim Naima'nın tanımında da görüleceği üzere devlet, mülk ve saltanatla eşdeğerdir. Dolayısıyla Aralık devlet tüzel kişiliği düşüncesi, ilk ortaya çıkmaya başladığı dönemde mülk ve saltanatla bütünlüğü cihetinden anlaşılmıştır.

Sonuç olarak Erken Modern Dönemde Osmanlıların kendini isimlendirmesinde hanedan isminin yeri korunmaktadır. Fakat bununla beraber zaman içinde hanedandan bağımsız müstakil bir devlet tanımlamasına ve dolayısıyla devlet tüzel kişiliğine zemin hazırlayacak şekilde yeni bir anlam dönüşümünün izini sürmek de mümkündür. Aşağıda, bu anlam dönüşümüne zemin hazırlayan siyasi gelişmeler üzerinde durulmuştur.

\section{DEVLET TÜZEL KİŞİLİĞİNIN TEŞEKKÜLÜ: HANEDANA KARŞI SULTAN VE SADRAZAM}

Osmanlı Devleti'nin klasik anlamda bir hanedanlık olduğu yukarıda belirtilmişti. Osmanlı'nın hanedan olma niteliği, şüphesiz ki devletin yıkılışına kadar devam etmiştir. Fakat bundan farklı olarak burada ele alınacak esas konu, hanedandan ve daha sonra padişahtan bağımsız bir devlet anlayışı ve yönetim yapısının oluşum seyrini takip edebilmektir. Nitekim bir devlet tüzel kişiliğinin oluşumundan bahsedebilmek için öncelikle ülkenin bizatihi sahibi olan gerçek kişi ya da kişilerden bağımsız kurumsal bir organizasyon olarak devletten; kısacası görece bağımsız bir bürokrasiden bahsedebilmek gerekmektedir.

Osmanlı için klasik anlamda devlet bürokrasisi denilen şey, başlangıçta padişah kapısından başka bir şey değildir. Başlıca karar 


\section{Osmanlı Erken Modern Döneminde Egemenliğin Sürekliliği Sorunu ve Devlet Tüzel Kişiliğinin Gelişimi (1453-1617)}

mercii olan Divan-ı Hümayun ise padişahın divanıdır ve padişahın sarayında toplanır. Bütçe de hakeza Havass-ı Hümayun yani padişahın şahsî hazinesidir. Fakat ilk örneklerine on altıncı yüzyılda rastlanan ve kendilerine dirlik tahsis edilen kâtipler, bu dirlik gelirleri sayesinde padişahın hazinesinden bağımsız ve farklı bir gelir kaynağına sahip olmaları dolayısıyla bağımsız devlet bürokrasisinin modern dönem öncesindeki ilk örnekleri olarak kabul edilebilir (Kunt, 1999: 35).

Yine on altıncı yüzyılda ortaya çıkan iki önemli gelişme, padişah kapısı ile özerk bir müstakil devlet yapılanmasının birbirinden ayrılması sürecinin ilk örnekleri sayılabilir. Bunlardan birincisi, askeri komutada yaşanan dönüşümdür. Normal şartlarda bizzat padişah komutasında sefere çıkan ordunun farklı cephelerde aynı anda savaşmak gerektiğinde padişahın komutasında değil; sadrazamın veya başka bir vezirin komutasında sefere çıktıklarında bu durumu çok yadırgadıkları bilinmektedir. Fakat zamanla kabullenilen bu durum, itaat anlamında padişaha bağlı fakat fiili olarak padişahın başında bulunmadığı bir örgütsel yapının ortaya çıkışına işaret etmekteydi. İkincisi ise hazine giderlerinin padişah kapısı dışında da kullanılmaya başlanması ile ilgilidir. Askeri sebeplerle sınır bölgelerinde kale yapımı ya da onarımı için gerekli maddi giderlerin yerel kaynaklardan karşılanmasının mümkün olmadığı durumlarda Havass-1 Hümayun'dan karşılanması, padişah hazinesinin padişah kapısı-üstü olarak tanımlanabilecek devlet giderlerine tahsis edilmesi anlamina geliyordu (Kunt, 1999: 35).

Padişah ile müstakil bir devlet yapılanmasının birbirinden ayrılması sürecinin ilk örnekleri olarak değerlendirilen bu iki durumdan başka, bu ayrışma sürecinde etkili olan esas unsur ise Divan-1 Hümayun'un gelişimi ve buna bağlı olarak sadrazamın değişen konumu olmuştur. Dîvân-1 Hümayun, tam gelişmiş şeklini Fâtih Sultan Mehmed zamanında almaya başlamıştır. Fâtih Kanunnamesi bir çeşit devlet teşkilatlanması düzeni kurmuş ve devletin belli başlı makamlarını; bu arada Dîvân-1 Hümâyun'u da düzenlemiştir. Fâtih Sultan Mehmed'in kanunnâmesi, devlet teşkilatlanmasını düzenleyen türde tek kanunnamedir. Sonraki padişahlar döneminde devlet teşkilâtıyla ilgili düzenlemeler yapılmışsa da bunlar kapsamlı olmamıştır (İnalcık, 2011: 31). Ayrıca Fatih, kendisinden sonraki hükümdarları da bağlayıcı şekilde kanunname ferman etmiş olması (İnalcık, 2001: 335) dolayısıyla her sultanın saltanat dönemiyle sınırlı olan kanun ve 
nizam anlayışını da aşarak egemenlikte sürekliliğin sağlanmasına katkı sunmuştur.

Bu süreçte Fâtih'in getirdiği en büyük yenilik ise divanda padişahın başkanlığının kaldırılarak yerinin sadrazama bırakılmasıdır. Bu dönemde hükümdar karşısında kendisine hiçbir yetki verilmemekle birlikte sadrazamın siyasi yetkileri artırılmış; böylece Dîvân-1 Hümâyun'un yetkileri de yavaş yavaş sadrazamın divanı olan İkindi Divanı'na aktarılmaya başlamıştır. Öyle ki on sekizinci yüzyıla gelindiğinde $B \hat{a} b-\imath$ Âsafí olarak adlandırılan sadrazam dairesinin her Münşeat üs-Selatin adlı eserinde, Divan-1 Hümayun'da devlet siyasetini belirleyen kişinin sadrazam olduğunu açık bir şekilde belirtmektedir. Örneğin Sokullu Mehmet Paşa'nın (1505-1579) önceden ikinci vezir olarak bulunduğu divanda izlenen siyaseti kabullendiği fakat kendisi sadrazam olunca kendi siyasetini uygulamaya başladığı bilinmektedir. Yine Feridun Ahmet Bey'in sadrazam için kullandığı devlet-i hazret-i vezir-i azam ifadesi, padişah kapısı dışında gelişmekte olan farklı bir siyasi yapıyı ifade etmektedir. Fakat bununla beraber padişahın devam- $\imath$ devleti vurgusuyla da devletin padişahın devleti olduğu vurgulanmaktadır (Kunt, 1999: 35).

Anlaşılacağı üzere Osmanlı Erken Modern dönemi, padişahtan bağımsız bir bürokrasinin şekillenmesiyle birlikte, devlet tüzel kişiliğinin de ilk nüvelerini verdiği bir dönemi ifade etmektedir. Fakat hemen belirtmek gerekir ki bu dönemde tek başına müstakil bir devlet telakkisinden değil; ancak hanedan ve sultanla bir ve bütün olarak anlaşılabilen bir devlet telakkisinden bahsedilebilir.

\section{TAHTIN TEVARÜSÜ: EGEMENLIKTE SÜREKLİLIĞIN BIR UNSURU OLARAK CÜLUS}

Osmanlı Devleti için ilk süreklilik tartışması, onun Oğuz/Türkmen geleneğinin ve Selçukluların bir devamı sayılıp sayılamayacağı üzerine yoğunlaşır. Osmanlı tarihi içinde Yazıcızade (?-?) ve Aşıkpaşazade (1400-1484) gibi resmi tarih yazıcıları, devletin 


\section{Osmanlı Erken Modern Döneminde Egemenliğin Sürekliliği Sorunu ve Devlet Tüzel Kişiliğinin Gelişimi (1453-1617)}

Oğuz/Türkmen soyundan gelen; o geleneği sürdüren ve Selçuklu varisi sayılan yönüne vurgu yapmaktadırlar (Bulduk, 1999: 162, 164165). Bu vurgunun erken dönemdeki temel sebebi, aslında Timur ve oğlu Şahruh karşısında Osmanlıların kendi meşruiyetini sağlama arayışı olarak görülebilir (İnalcık, 1959: 77; Bulduk, 1999: 161; İnalcık, 2003: 62). Ancak burada tartışlacak olan konu bununla bağlantıll; fakat bundan farklı olarak Osmanlı Devleti'nin kendi içerisindeki süreklilik sorununa ilişkindir.

Kantorowicz (2018: 417)'e göre, Yüksek Orta Çağda İngiltere örneğinde kralın ölümünden sonra yerine yeni kral tahta geçene kadar geçen ara dönemde halkın kendilerinde hırsızlık yapma ve daha başka huzursuzluklar çıkarma hakkının doğduğunu iddia etmesi söz konusu olmuştur. Bu iddianın temel dayanağı, kralın olmadığı yerde bağlayıcı bir yasa veya hukukun da olmadığı savıdır. Yani aslında her kral kendi başına bir yasa koyucu ve egemendi. Buradan anlaşılan şudur ki krallar arası geçiş dönemlerinde egemenliğin devamını teminat altına alacak bir süreklilik unsuru ve bir devlet tüzel kişiliği anlayışı yoktu. İngiltere'de ilkin kralın olmadığ 1 ara dönemde İsa Mesih'in geçici olarak kral olduğu savıyla ve daha sonraları hanedanlığın kendisinin asla ölmeyen birey-üstü kurum olduğu saviyla bu sorunun aşıldığı görülmektedir. Soyut/düşünsel planda bir süreklilik unsuru sağlayan bu düşünceyi pekiştiren esas gelişme ise 1272 yılında tahtın en büyük erkek evladın doğuştan gelen hakkı olduğunun -özel bir kanun ya da hükme bağlanmasa bile- de facto olarak kabul edilmesi olmuştur. Dolayısıyla bu tarihten itibaren mevcut kralın ölümüyle birlikte tahtın varisi olan en büyük erkek evlat, kendiliğinden kral olmaktadır (Kantorowicz, 2018: 433-434).

Osmanlı tecrübesinde de bu süreklilik sorununa benzer bir sorun mevcut görünmektedir. Fakat Osmanlı'daki sorun, hanedanın sürekliliği değil; egemenliğin ya da başka bir deyişle -artık egemen bizatihi sultanın kendisi olduğu için- saltanatın sürekliliği sorunuydu. Bir padişah öldüğünde, bütün görevlendirmeler ve yasal düzenlemeler yeni padişah tarafından onanıncaya kadar geçersiz sayılmaktaydı. Dolayısıyla padişahsız ara dönemlerde mevcut bir egemenin olmadığı gerekçesiyle kapıkulları kendilerini yağma ve taşkınlık yapma hakkına sahip görmekteydiler. Bu sorunun, İngiltere örneğine benzer şekilde ancak I. Ahmet Döneminde (1603-1617) kafes 
sistemine geçilmesi sonucu saltanatta devamlılığının sağlanmasıyla aşılabildiği görülmektedir (İnalcık, 2003: 67).

Öte yandan İngiltere'de hanedanlar değişebilirken Osmanlı'da hanedanın değişmesi düşüncesinin, Fatih Sultan Mehmed dönemine gelindiğinde hanedanın sürekliliği açısından bir tehdit olmaktan çıktığı anlaşılmaktadır. Fakat bunun öncesinde, özellikle siyasi bunalımların etkisiyle bu kabil düşüncelerin nüvelendiği söylenebilir. Özellikle Fetret Devri'nde Şeyh Bedreddin'in (1359-1418) ve Şahkulu'nun (?-1511) padişahlık iddiasında bulunması, II. Murad Döneminde (1421-1444/1446-1451) Balkanlarda yaşanan bunalım sonrasi uc beylerinin sultana tepkisi ile III. Mehmed (1595-1603) ve II. Osman Dönemlerinde (1618-1622) gelişen isyan hareketleri doğrudan hanedana yönelik bir karşı çıkış mahiyeti kazanmış görünmektedir. Dolayısıyla on beşinci yüzyılda kaleme alınan Osmanlı tarihine dair eserlerin hanedanı Oğuz Han soyuna dayandırmasının ve Kayı Boyu'nun kut sahibi olduğunu ifade etmesinin, Timurlulara karşı bir üstünlük iddiasının yanı sıra hanedana kastedebilecek beyler üzerinde de bir üstünlük iddiasını içerdiği söylenebilir. Fakat Fatih Sultan Mehmet Döneminde (1451-1481) -her ne kadar bu durum yukarıda belirtildiği üzere sonradan tekrar değişse de- hanedanın değişimine dair düşüncelerin ortadan kalktığ1 görülmektedir (Emecen, 2011: 3941, 45-47). Dolayisıyla -en azından bu dönemden itibaren- artık Osmanlı hanedanı olmadan bir Osmanlı Devleti'nden bahsetmek mümkün değildir (İnalcık, 2003: 65). Nitekim hanedanın varlığına kastetmemekle birlikte iktidara ortak olma niyetinde olabilecek aristokratik unsurlar dahi Fatih Döneminde yapılan kanuni düzenlemelerle devre dışı bırakılmıştır (Karatepe, 1997: 41). Bizanslı diplomat ve tarihçi Dukas'ın (1400?-1462?), "hem eski hem de yeni hükümdar Osman soyundan geldiği sürece, bir tebaanın bağlllı̆̆ını birinden diğerine kolaylıkla aktardığını" (Peirce, 1996: 17) ifade etmesi, bu duruma kanit olarak gösterilebilir. Bu durum, hanedanın sürekliliğinin sağlandığını gösteren bir örnek olarak nitelendirilebilir.

Özetle, Osmanlı hanedanının değişebilirliğine yönelik kimi fikir ve eylemler özellikle siyasi bunalım dönemlerinde belli bir karşıllık bulmuş olsa da sonuçta bunlar, hanedanın sürekliliği açısından ciddi sonuçlar doğuracak mahiyette birer badireye dönüşmemiş görünmektedir. $\mathrm{Bu}$ sayede hanedan içinden gelen padişahlar değişebilmekle birlikte yönetici hanedan, yıkılışa değin yüzyıllarca ayakta kalabilmiştir. Böylesi uzun soluklu bir hanedanlığın İslam 


\section{Osmanlı Erken Modern Döneminde Egemenliğin Sürekliliği Sorunu ve Devlet Tüzel Kişiliğinin Gelişimi (1453-1617)}

dünyasında bir benzerinin bulunmaması da ayrıca dikkat çekicidir (Peirce, 1996: 17).

Öte yandan Osmanlılar için süreklilik sorununu doğuran esas unsur, hanedanlığın değil saltanatın sürekliliği sorunudur ki bu sorun en azından İngiltere' deki senioratus gibi I. Ahmet Döneminde ekber-erşed sistemine geçinceye değin bir padişah öldüğünde yerine geçecek şehzadenin kim olacağını belirleyen kesin bir kuralın olmamasından kaynaklanmaktadır. Bununla beraber, o dönemde devletin en önemli askeri güçlerinin ucta olması sebebiyle büyük şehzadeye uc sancağının verilmesiyle birlikte en büyük kardeş, fiili olarak tahtın en güçlü adayı haline geliyordu. Fakat yine de hanedanın tüm üyeleri, hâkimiyet hakkına sahipti. Padişah da kendisinden sonra yerine geçmek üzere oğullarından birisini veliaht tayin edebilmekteydi. Ancak veliahtlık da hükümdar öldükten sonra bağlayıcılığını kaybetmekteydi (İnalcık, 1959: 82, 87). Şu hâlde denilebilir ki tahta kimin geçeceğini belirleyen genel bir kural olmamakla birlikte, tahta aday şehzadelerin adaylığını güçlendiren hukuki ve siyasi etmenler de olabilmekteydi.

Diğer taraftan tahta geçecek olan şehzadenin nasıl ve nerede tahta geçeceği sorunu da süreklilik tartışmasını aydınlatabilmek açısından bazı ipuçları sunmaktadır. 1566'da Kanuni'nin ölümü üzerine Şehzade Selim'in tahta cülus yöntemi, buna iyi bir örnek oluşturmaktadır. Buradaki birinci sorun, Kanuni'nin savaş meydanında ölmüş olması dolayısıyla yeni padişahın Zigetvar'daki ordugâhta mı yoksa başkent olan İstanbul'da mı tahta cülus edeceği sorunudur. İkinci sorun ise şehzadenin vali olarak bulunduğu Kütahya'daki kendi kapıkulu ve danışman çevresi ile İstanbul'daki padişah kapıkulu ve çevresinin nasıl bağdaştırılacağı sorusudur.

Birinci sorunla ilgili Sadrazam Sokullu Mehmet Paşa'nın (1505-1579) Şehzade Selim'e önerisi, kendisinin bir an evvel ordunun bulunduğu yere gelerek orada babasının kapıkulları önünde tahta çıkmasıydı. Şehzade Selim'in yanındaki danışman çevresi ise ordunun ve sadrazamın ayağına gitmektense İstanbul'da sarayda tahta çıkmasını tavsiye etmişlerdir. Bu tavsiyenin arka planında şehzade kapısının padişah kapısına dönüşmesi sayesinde Kütahya'daki şehzade çevresinin kendilerine devlet makamlarında önemli yerler edinme kaygısı görülse de tahta cülusun nerede olması gerektiği noktasındaki belirsizlik de ortadadır. Buradan çıkarılacak esas soru ise şöyle 
olmalıdır: devlet padişahtan bağımsız ve müstakil bir kurum olarak başkent İstanbul'da mıdır; yoksa devlet padişahtır ve başkent de padişahın bulunduğu yer midir? Bu soruya cevap vermeyi sağlayacak eski bir cülus örneği yoktu. Dolayısıyla görünen o ki bu sorunun Şehzade Selim için de net bir cevabı yoktu. Nitekim Şehzade Selim, kendi danışmanlarının tavsiyelerine uyarak önce İstanbul'da tahta cülus etmiştir. Ardından da Sokullu Mehmet Paşa'nın ısrarı üzerine Zigetvar Seferi'nden dönmekte olan ordunun başına gelerek ordugâhta tekrar tahta cülus etmiştir (Kunt, 1999: 38).

İkinci sorunla ilgili olarak ise II. Selim'in tahta cülus sonrasinda geciktirmeden cülus bahşişini vermesi ve dirliğe çıkmada kapıkulunu kayırması gibi tutumları, "babasından devraldığı vezirler ve saray halkına yanaşıp şehzadelik erkânını ve askerini geri çekmek suretiyle saltanat değişiminde devlette devamlılık ve sürekliliği kollama çabası olarak görülmeli" dir (Kunt, 1999: 38).

Dolayısıyla II. Selim örneğinden hareketle son tahlilde on altıncı yüzyıldan itibaren bir süreklilik unsurunun gözetilmeye başlandığ görülmektedir. Sonrasında ise halkın merkezî idareden beklentilerinin artması ve çeşitlenmesi neticesinde saltanatın daha üstün ve dolayısıyla daha simgesel bir duruma geldiği; devletin ise giderek sadrazamın idaresinde olan bir yapıya dönüştüğü söylenebilir. Böylece aslında devlet ve saltanat kavramlarının da bir bütünü tamamlayan kavramlar olmakla birlikte birbirinden ayrıştığı (Kunt, 1999: 40) ve padişahın, bir halife ve imparator gibi mutlak egemen olarak görülmeye devam etmesinin (İnalcık, 1959: 94) yanı sıra Orta Asya-Türk geleneğinden tevarüs eden ve saltanatta vücut bulan devlet tasavvurundan farklı ve kiymeti kendinden menkul bir devlet tasavvurunun da ortaya çıktığı savunulabilir. Dolayısıyla II. Selim'den bir nesil sonra, Naima'nın -yukarıda bahsedildiği üzere- derli toplu bir devlet tanımı yapabilmesinin zeminini hazırlayan arka planın, yaşanan bu anlam dönüşümünde aranması gerekir.

\section{SONUÇ}

Çalışma boyunca birbiriyle bağlantılı iki sorun olarak Osmanlı'da devlet tüzel kişiliğinin gelişimi ve egemenliğin sürekliliği sorunu tartışılmıştır. Bu bağlamda öncelikle egemenliğin önceleri hanedanda 


\section{Osmanlı Erken Modern Döneminde Egemenliğin Sürekliliği Sorunu ve Devlet Tüzel Kişiliğinin Gelişimi (1453-1617)}

tecessüm ederken daha sonra padişahın şahsında toplandığı vurgulanmıştır.

Devlet tüzel kişiliğinin gelişimi ile ilgili ipuçları ise Osmanlıların kendilerini nasıl isimlendirdikleri sorunu üzerinden takip edilmiştir. Buradan çıkarılacak sonuç, Osmanlıların kendini isimlendirmesinde hanedan isminin başından beri kullanılageldiği ve yerini koruduğu; fakat bununla beraber özellikle Naima'nın devlet tanımlamasıyla birlikte zaman içinde hanedandan bağımsız müstakil bir devlet tanımlamasına yani devlet tüzel kişiliğine zemin hazırlayacak şekilde yeni bir anlam dönüşümünün izini sürmenin de mümkün olduğu yönündedir.

Devlet tüzel kişiliğinin gelişimi ise devlet içerisindeki merkezi güç odaklarının değişimi/dönüşümü üzerinden açılanmaktadır. Buna göre, ilk olarak kendilerine dirlik tahsis edilen kâtiplerin bağımsız gelir kaynağına sahip olmaları ve böylece bağımsız bir bürokrasinin doğuşuna temel oluşturması üzerinden; ikinci olarak padişahın ordunun başında bulunmadığı durumlar sebebiyle farklı askeri komuta kademelerinin orduyu komuta etmesi üzerinden; üçüncü olarak padişah hazinesinin dış harcamalara da açılması ve bu sebeple padişahın şahsi hazinesi olmaktan çıkması üzerinden; son olarak Divan-1 Hümayun'un gelişmesi ve buna bağlı olarak sadrazamın konumunun güçlenmesi üzerinden Osmanlı'da devlet tüzel kişiliğinin gelişiminin erken dönemdeki izlerini sürmenin mümkün olduğu sonucuna ulaşılmaktadır.

Çalışmada konu edinilen süreklilik sorunuyla ilgili tartışma ise padişahların tahta cülusu üzerinden izlenebilmektedir. Buradaki birinci husus, tahta kimin geçeceği; ikinci husus ise nasıl ve nerede geçeceğidir. Birinci hususla ilgili olarak varılan sonuç, tahta kimin geçeceğini belirleyen genel bir kuralın olmaması sebebiyle bir süreklilik sorununu içinde barındırdığı; fakat hanedanın sürekliliğiyle ilgili kayda değer bir tartışmanın bulunmadığ1 yönündedir. Bununla birlikte özellikle on beşinci yüzyıldan itibaren hanedanın önemini kaybederek padişahın mutlak egemenliği anlayışının yerleşmesiyle ve soyut ve padişahtan ayrı bir devlet düşüncesinin gelişmeye başlamasılla süreklilik sorunun da farklı bir boyut kazandığ yönündedir. Nitekim II. Selim'in cülusu örneğinde de görüldüğü üzere, tahta yeni cülus eden padişahın kendisini başkent İstanbul'daki 
padişah kapısı çevresinde konumlandırması, saltanat değişimi sırasında devlette sürekliliği gözettiğine işaret etmektedir.

Tüm bunlardan hareketle 1453-1617 tarih aralığ1 bir bütün olarak değerlendirildiğinde, Osmanlı'da önce hanedandan bağımsız ve mutlak saltanat anlayışının ve daha sonra sultandan bağımsız ve müstakil bir devlet anlayışının gelişiminin ve dolayısıyla süreklilik sorununu belli ölçüde aşmış, kıymeti kendinden menkul bir devlet tüzel kişiliğinin oluşumunun erken dönemdeki izini sürmek mümkündür. Sürülen bu iz, modern devletlerin henüz ortaya çıkmakta olduğu bir dönemde, modern devletin belirleyici unsurları olan egemenlik, süreklilik ve tüzel kişilik gibi unsurların Osmanlı'da modernleşme hareketleriyle birlikte modern ve merkezi/mutlak devletin oluşumuna giden süreçte nasıl bir rol oynadığının tarihsel ve düşünsel arka planını izah etmesi açısından önemi haizdir. 


\section{Osmanlı Erken Modern Döneminde Egemenliğin Sürekliliği Sorunu ve Devlet Tüzel Kişiliğinin Gelişimi (1453-1617)}

\section{KAYNAKÇA}

Akyılmaz, Gül (1999). “Osmanlı Devleti'nde Egemenlik Kavramının Gelişimi”. Selçuk Üniversitesi Hukuk Fakültesi Dergisi,7(1-2), 129-159.

Bodin, Jean (2003). On Sovereignty. (Çev. J. H. Franklin). Cambridge: Cambridge University Press.

Bulduk, Üçler (1999). “Osmanlı Beyliği'nin Oluşumunda Oğuz/Türkmen Geleneğinin Yeri”, Eren, G. (Ed.). Osmanlı 1 Siyaset, Ankara: Yeni Türkiye Yayınları.

Emecen, Feridun (2011). Osmanl Klasik Çağında Hanedan, Devlet ve Toplum. İstanbul: Timaş Yayınları.

Emecen, Feridun (2012). İlk Osmanlılar ve Batı Anadolu Beylikler Dünyası. İstanbul: Timaş Yayınları.

Güngör, Erol (1996). Tarihte Türkler. İstanbul: Ötüken Yayınları.

Heywood, Andrew (2014). Siyaset Teorisine Giriş. (Çev. Hızır Murat Köse). İstanbul: Küre Yayınları.

İnalcık, Halil (1959). “Osmanlılar'da Saltanat Veraseti Usûlü ve Türk Hakimiyet Telakkisiyle İlgisi”. Ankara Üniversitesi Siyasal Bilgiler Fakültesi Dergisi, 13(1), 69-94.

İnalcık, Halil (1965). Adaletnameler. Ankara: Türk Tarih Kurumu Yayınları.

İnalcık, Halil (2001). "Kanunnâme", Türkiye Diyanet Vakf1 İslam Ansiklopedisi. C. 24. İstanbul: Türkiye Diyanet Vakf1 Yayınları, 333-337.

İnalcık, Halil (2003). Osmanlı İmparatorluğu Klasik Çă̆ (1300-1600). İstanbul: Yapı Kredi Yayınları.

İnalcık, Halil (2011). Osmanlı İdare ve Ekonomi Tarihi. İstanbul: Türkiye Diyanet Vakfı İslâm Araştırmaları Merkezi (İSAM).

İpşirli, Mehmet (2007). Tarih-i Na'ima Ravzatü'l Hüseyn Fî Hulasati Ahbari'lHafikayn Cilt I. Ankara: Türk Tarih Kurumu Yayınları.

Kafesoğlu, İbrahim (1980). Kutadgu Bilig ve Kültür Tarihimizdeki Yeri. İstanbul: Kültür Bakanlığı Yayınları.

Kafesoğlu, İbrahim (1997). Türk Milli Kültürü. İstanbul: Ötüken Yayınları.

Kantorowicz, Ernst H. (2018). Kralın İki Bedeni. Ankara: BilgeSu Yayıncılık.

Karatepe, Şükrü (1997). Darbeler, Anayasalar ve Modernleşme. İstanbul: İz Yayıncilık.

Kösoğlu, Nevzat (1997). Devlet: Eski Türklerde, Íslam'da ve Osmanlı'da. İstanbul: Ötüken Yayınları. 


\section{Ensar KIVRAK}

Kunt, Metin (1999). Devlet, Padişâh Kapısı ve Şehzade Kapıları. Eren, G. (Ed.). Osmanlı 6 Teşkilat, Ankara: Yeni Türkiye Yayınları.

Mumcu, Ahmet (1994). "Divan-1 Hümayun", Türkiye Diyanet Vakfı İslam Ansiklopedisi, C. 9, İstanbul: Türkiye Diyanet Vakfı Yayınları, 430-432.

Neumann, Christoph K. (1999). “Devletin Ad1 Yok - Bir Amblemin Okunması". Cogito, 19, 269-283.

Özdemir, Gürbüz (2009). “Batı'da ve Türklerde Egemenlik Kavramı”. Dumlupınar Üniversitesi Sosyal Bilimler Dergisi, 23, 1-11.

Peirce, Leslie P. (1996). Harem-i Hümayun Osmanlı İmparatorluğu'nda Hükümranlık ve Kadınlar. (Çev. Ayşe Berktay). İstanbul: Tarih Vakfı Yurt 712 Yayınları.

Strayer, Joseph R. (2020). Modern Devletin Kökenleri. İstanbul: Say Yayınları.

Taşağıl, Ahmet (1992). Türklerde İnsani Değerler ve İnsan Hakları Başlangıcından

Osmanl Dönemine Kadar. İstanbul: Türk Kültürüne Hizmet Vakfı Yayınları.

Uslu, Ateş (2017). Siyasal Düşünceler Tarihine Giriş. İstanbul: Tarih Vakfı Yurt Yayınları. 


\section{Osmanlı Erken Modern Döneminde Egemenliğin Sürekliliği Sorunu ve Devlet Tüzel Kişiliğinin Gelişimi (1453-1617)}

\section{SUMMARY}

In this study, the transformation of the sovereignty understanding from the Ancient Turks to the Ottoman was briefly mentioned. As a matter of fact, in order to talk about the development of a state legal entity and the continuity of the state, it is necessary to decide who the sovereign is in this process. In this process, the dynasty as a whole was previously regarded as sovereign. From its foundation, the Ottoman Empire was a dynasty like all other states of the era. The authority to rule belonged to the dynastic family. The person who has bestowed the authority to rule from within the dynasty became the sultan. But then, the sovereignty began to take shape in the sultan himself. Thus, starting from the fifteenth century, the state was no longer considered a common heritage of the dynasty. The Sultan was seen as the sole owner of the sovereignty.

In order to show that a state conception independent of the dynasty and the sultan, in fact, a state legal entity, developed in a historical process, the question of how the Ottomans named themselves were answered. The question of how the Ottomans, which emerged as a seigniory, named themselves may help to understand the transformation from dynasty to a state consideration. The place of the dynasty name has always been preserved in the Ottomans' naming themselves. However, during the Early Modern Period, it is also possible to trace a new transformation of meaning, which paves the way for the definition of the state independent from the dynasty. In the beginning, the Ottomans called themselves "Al-i Osman", later the term "Devlet-i Aliyye" emerged. This term, which does not include the name of the dynasty and includes the word devlet (state), refers to the state legal entity. Thus, clues about the development of the state legal entity can be identified through the issue of naming the state. In this way, the change in the nomenclature of the state has been presented as evidence of the development of the state legal entity.

Thus, the development of a state consideration independent from the dynasty and the sultan was revealed. Then, the development process of this consideration was followed through the change and transformation of central power centers within the political organization.

In order to talk about the formation of a state legal entity, first of all, it is necessary to talk about the state as an institutional organization independent of the real person or persons who own the country, in short, a relatively independent bureaucracy. The Ottoman Early Modern period was a period in which the state legal entity gave its first cores in parallel with the formation of an independent bureaucracy from the sultan. However, it should be noted immediately that an independent state consideration cannot be mentioned 
alone in this period. However, one can talk about a state consideration that can be understood as a whole with the dynasty and the sultan.

Two important developments that emerged in the sixteenth century can be considered as the first examples of the process of separating the autonomous and independent state structure from the sultan. The first of these concerns the transformation in military command. An example of this situation is an army that was not actually headed by the Sultan. The second of these concerns the use of the treasure. In cases where the financial expenses required for the construction or repair of the fortress in the border regions for military reasons could not be met from local resources, it meant that the sultan's treasury was allocated to the state expenses. Apart from these two situations, an important factor in this separation process was the development of the Divan-ı Hümayun and the changing position of the grand vizier accordingly. In this context, the restructuring of the Divan-ı Hümayun during the reign of Fatih Sultan Mehmet constitutes an important step in the premodern bureaucratic organization.

Finally, in the study, the problem of the continuity of sovereignty in the Ottoman Empire is discussed, based on the example of the throne of the Ottoman sultans. As a matter of fact, the formation of an ever-existing state perception and actually the state being seen as a legal entity is closely related to ensuring the continuity of sovereignty.

During the interim periods without a sultan that emerged when a sultan died, the soldiers considered themselves entitled to plunder and raid because there was no existing sovereign. This problem could only be overcome in the period of Ahmet I, thanks to the transition to the cage system. But before, as seen in the example of II. Selim, an element of continuity has begun to be observed since the sixteenth century. Later, as a result of the increase and diversification of the people's expectations from the central administration, the sultanate became superior and thus more symbolic. Therefore, the state has gradually turned into a structure under the administration of the grand vizier.

Based on all these, when the date range of 1453-1617 is considered as a whole, it is possible to trace the early development of a state legal entity that has exceeded the continuity problem to a certain extent and whose value is selfevident. 